QUALITY

Volume 8, Nomor 2, 2020, 219-240

\title{
Pendidikan Karakter sebagai Basis Revolusi Mental Guru Madrasah Aliyah di Kabupaten Demak
}

\author{
Saiful Mujab \\ IAIN Kudus, Kudus, Indonesia \\ saifulmujab@gmail.com
}

\begin{abstract}
Abstrak
Melihat keadaan karakter dan gejala krisis moral bagi anak bangsa yang semakin menipis dan merosot sekarang ini. Maka diperlukan sebuah pola pendidikan karakter yang berbasis pada revolusi mental. Penelitian ini bertujuan untuk mengungkap pendidikan karakter sebagai basis revolusi mental yang dilakukan oleh guru Madrasah Aliyah (MA) di Kabupaten Demak. Penelitian tentang pendidikan karakter sebagai basis revolusi mental ini dilakukan dengan menggunakan metode riset lapangan (field research) dengan subjek penelitian guru Madrasah Aliyah (MA) di Kabupaten Demak. Data penelitian yang terkumpul kemudian dianalisis dengan menggunakan dengan teknik analisis deskriptif kualitatif yaitu dengan pendekatan deduktif dan pendekatan induktif. Hasil penelitian menunjukkan bahwa pendidikan karakter sebagai basis revolusi mental yang dilaksanakan oleh guru Madrasah Aliyah (MA) di Kabupaten Demak yaitu; (1) secara normatif pendidikan karakter sebagai basis revolusi mental merujuk pada al-Qur'an dan hadis, secara hukum merujuk pada Pancasila, UUD 1945, UU No. 20 Tahun 2003, Perpres No. 87 Tahun 2017, Pergub Provinsi Jawa Tengah No. 31 Tahun 2016, Perbup Kabupaten Demak No. 24 Tahun 2017, dan Perbup No. 75 Tahun 2017. (2) Tujuan pendidikan karakter sebagai basis revolusi mental selaras dengan tujuan pendirian NKRI seperti ditegaskan dalam Pembukaan UUD 1945 dan Tap MPR Nomor X/MPR/1998. (3) Penguatan pendidikan karakter sebagai basis revolusi mental sejalan dengan program Nawacita Presiden Joko Widodo (2014-2019) dan Trisakti Presiden Soekarno. (4) Nilai dasar pendidikan karakter sebagai basis revolusi mental berdasar pada pada enam pilar utama dari pendidikan karakter yang dikembangkan oleh Major. (5) Prinsip pelaksanaan pendidikan karakter sebagai basis revolusi mental, yaitu: (a) Berorientasi pada berkembangnya potensi peserta didik, (b) Keteladanan dalam penerapan pendidikan karakter, (c) Berlangsung melalui pembiasaan dan sepanjang waktu.
\end{abstract}

Kata Kunci: Pendidikan Karakter, Basis, Revolusi Mental 


\begin{abstract}
Seeing the condition of character and symptoms of a moral crisis for the nation's children who are getting thinner and degenerate nowadays. So we need a pattern of character education based on mental revolution. This study aims to reveal character education as the basis for the mental revolution carried out by Madrasah Aliyah (MA) teachers in Demak Regency. Research on character education as the basis for mental revolution was carried out using field research methods with the research subjects of Madrasah Aliyah (MA) teachers in Demak Regency. The collected research data is then analyzed using a qualitative descriptive analysis technique, namely the deductive approach and the inductive approach. The results showed that character education as the basis for mental revolution carried out by Madrasah Aliyah (MA) teachers in Demak Regency, namely; (1) Normatively character education as the basis for mental revolution refers to the Qur'an and Hadith, legally refers to Pancasila, the 1945 Constitution, Law no. 20 of 2003, Presidential Decree No. 87 of 2017, Pergub of Central Java Province No. 31 of 2016, Demak Regency Regulation No. 24 of 2017, and Perbup No. 75 of 2017. (2) The purpose of character education as a basis for mental revolution is in line with the objectives of establishing the Republic of Indonesia as emphasized in the Preamble to the 1945 Constitution and the MPR Decree Number X / MPR / 1998. (3) Strengthening character education as a basis for mental revolution in line with President Joko Widodo's Nawacita program (2014-2019) and President Soekarno's Trisakti. (4) The basic values of character education as the basis for mental revolution are based on the six main pillars of character education developed by Major. (5) The principles of implementing character education as a basis for mental revolution, namely: (a) Oriented to the development of the potential of students, (b) Exemplary in the application of character education, (c) Taking place through habituation and all the time.
\end{abstract}

Keywords: Character Education, Basis, Mental Revolution

\title{
A. Pendahuluan
}

Krisis moneter pada tahun 1998 telah mengakibatkan jatuhnya penguasa Orde Baru (12 Maret 1967-21 Mei 1998), pimpinan Presiden Soeharto pada tanggal 21 Mei 1998 (Edward Aspinall and Marcus Mietzner, 1998, Simorangkir, 2015). Selanjutnya pada tanggal 10 November 1998 bangsa Indonesia, yang diprakarsai oleh Forum Komunikasi Senat Mahasiswa Jakarta (FKSMJ), Senat ITB Bandung, dan Senat Universitas Siliwangi serta empat tokoh reformasi, yaitu Kyai Haji 


\section{Saiful Mujab}

Abdurrahman Wahid, M. Amien Rais, Sri Sultan Hamengkubuwono X dan Megawati Sukarnoputri, melaksanakan dialog kebangsaan di kediaman Gus Dur, di Ciganjur, Jakarta Selatan (Komara, 2015). Dalam dialog nasional tersebut menghasilkan 8 (delapan) kesepakatan, salah satunya adalah melaksanakan agenda reformasi sesuai kepentingan generasi bangsa. Karena agenda reformasi menjadi tujuan utama, maka pemerintahan selanjutnya disebut Pemerintah EraReformasi (Ida, 2014; Purnaweni, 2004), yaitu mereformasi sistem birokrasi pemerintahan yang tidak sehat dari pusat sampai daerah (Hamudy, 2010).

Pasca jatuhnya Orde Baru sampai sekarang presiden silih berganti mulai dari B.J. Habibie (21 Mei 1998-20 Oktober 1999), Kyai Haji Abdurrahman Wahid (20 Oktober 1999-23 Juli 2001), Megawati Soekarnoputri (23 Juli 2001-20 Oktober 2004), Susilo Bambang Yudhoyono (20 Oktober 2004-20 Oktober 2014), dan Joko Widodo(20 Oktober 2014 sampai sekarang) (Kardi, 2014). Namun setelah kuranglebih 20 tahun berlangsung, ternyata pembangunan di Era Reformasi belum juga membuahkan hasil seperti yang dicita-citakan, yaitu memberantas korupsi, kolusi dan nepotisme (KKN) yang menjadi fokus utama, malah sebaliknya ada kecenderungan krisis semakin melebar pada krisis multidimenasional, termasuk krisis mental (Aman, 2016).

Di era disruptif teknologi informasi yang semakin canggih, banyak anak bangsa yang menggunakan internet sebagai alat untuk memenuhi kebutuhan sosialnya (Fatmawati, 2020: 30). Dimana anak bangsa tidak memanfaatkan hal itu dengan sebaik-baiknya dengan perbuatan yang positif malah sebaliknya menyalahgunakan hingga terjadi kekerasan seksual, narkoba, tawuran dan lain-lainnya. Bahwa adanya revolusi mental yakni Mengubah mental peserta didik dan masyarakat bangsa secara revolusioner sebab terjadinya gejala krisis nilai dan karakter (Persada \& Pramono, 2017). Melihat keadaan karakter dan gejala krisis moral bagi anak bangsa yang semakin menipis dan merosot, jika keadaan ini dibiarkan saja maka bangsa Indonesia akan rusak dan dijajah oleh perkembangan yang semakin pesat yakni di era disruptif (Sholekhah, 2019). 


\section{Saiful Mujab}

Menurut Koentjaraningrat (2015: 51), secara faktual memang tidak dapat dipungkiri, bahwa kondisi karakter bangsa Indonesia demikian juga bangsa-bangsa lain di dunia pada umumnya dewasa ini sedang mengalami distorsi dan kemerosotan. Terbukti, hampir setiap hari di media sosial dan elektronik dapat disaksikan berbagai perilaku amoral. Karakter bangsa yang sebelumnya berpegang teguh pada agama dan nilai luhur, terus mengalami kemerosotan (David, 2005). Oleh karena itu, seruan dalam beberapa tahun terakhir untuk membangun kembali karakter bangsa melalui pendidikan karakter mendapat dukungan penuh seluruh elemen bangsa (Azra, 2010). Tidak terkecuali dari Presiden Joko Widodo dan Wakil Presiden Jusuf Kalla.

Praktek revolusi mental merupakan sebuah gerakan (movement) yang mana cita-cita besarnya adalah menjadikan insan yang berintegritas, mau bekerja keras, dan mempunyai semangat gotong royong. "Revolusi Mental adalah suatu gerakan untuk menggembleng manusia Indonesia agar menjadi manusia baru, yang berhati putih, berkemauan baja, bersemangat elang rajawali, berjiwa api yang menyalanyala". Sehingga gerakan ini merupakan gagas-an revolusi mental yang pertama kali dilontarkan oleh Presiden Soekarno pada Peringatan Hari Kemerdekaan 17 Agustus 1956. Soekarno melihat revolusi nasional Indonesia saat itu sedang mandek, padahal tujuan revolusi untuk meraih kemerdekaan Indonesia yang seutuhnya belum tercapai.

Revolusi di jaman kemerdekaan adalah sebuah perjuangan fisik, perang melawan penjajah dan sekutunya, untuk mempertahankan Negara Kesatuan Republik Indonesia. Kini, 75 tahun setelah bangsa kita merdeka, sesungguhnya perjuangan itu belum, dan tak akan pernah berakhir. Kita semua masih harus melakukan revolusi, namun dalam arti yang berbeda. Bukan lagi mengangkat senjata, tapi membangun jiwa bangsa (Mohamad Abdul Roziq Asrori, 2017).

Untuk merealisasikan pendidikan karakter, presiden menelurkan Peraturan Presiden RI Nomor 87 Tahun 2016 tentang Penguatan Pendidikan Karakter (PPK). Pada Bab I Ketentuan Umum, Pasal 1 Ayat (1) dijelaskan bahwa yang dimaksud PPK adalah gerakan pendidikan di bawah naungan satuan pendidikan untuk 


\section{Saiful Mujab}

memperkuat karakter siswa melalui harmonisasi olah hati, olah rasa, olah pikir, dan olah raga dengan melibatkan dan kerjasama antara satuan pendidikan, keluarga, dan masyarakat sebagai bagian dari Gerakan Nasional Revolusi Mental (GNRM). Revolusi sendiri berasal dari bahasa Latin revolutio, yang berarti berputar arah, yaitu perubahan fundamental (mendasar) dalam kerangka kekuatan atau organisasi yang terjadi dalam waktu yang relatif singkat. Kata kuncinya adalah Perubahan dalam Waktu Singkat. Revolusi mental merupakan suatu gerakan seluruh masyarakat baik pemerintah atau rakyat dengan cara yang cepat untuk mengangkat kembali nilai-nilai strategi yang diperlukan oleh bangsa dan negara sehingga dapat memenangkan persaingan di era globalisasi. Revolusi mental merubah perspektif (cara pandang), mindset (pikiran), sikap dan perilaku yang bertujuan pada peradaban dan kemoderenan, sehingga menjadikan bangsa besar dan dapat berkompetisi dengan bangsa-bangsa lain di dunia.

Hubungannya dengan Indonesia, kajian revolusi mental semula dikeluarkan Presiden Republik Indonesia pertama Soekarno dalam pidato kebangsaan dalam peringatan proklamasi kemerdekaan tanggal 17 Agustus 1957. Menurut Soekarno, revolusi mental adalah semacam gerakan hidup baru untuk menjadikan manusia Indonesia menjadi manusia baru, yang memiliki hati bersih, berkemauan baja, bersemangat Elang Rajawali, dan berjiwa api. Bagi Soekarno manusia baru dimaksud adalah manusia Indonesia berkarakter. Katanya: "Berikanlah saya 10 pemuda, maka akan aku guncang dunia (Edward \& Markus, 2010; Soekarno, 2015).

Menurut Presiden Jokowi, revolusi mental bertujuan untuk menegakkan kedaulatan, mengembangkan daya saing, dan memperkuat persatuan bangsa. Kita perlu melakukan revoluasi mental (M. Abdur Rozak Asrori, 2016; Noor, 2016). Hal ini sejalan dengan visi pemerintahan Joko Widodo dan Jusuf Kalla, yaitu: Terwujudkan Indonesia yang berdaulat, mandiri, dan berkepribadian, berlandaskan gotong royong (Widjiastuti, 2016). Sedang menurut Arif Budimanta, revolusi mental adalah gerakan kebangsaan untuk merubah cara perspektif (cara pandang), Mindset (pola piker), sikap-sikap, norma-norma, dan perilaku bangsa Indonesia 


\section{Saiful Mujab}

untuk mewujudkan Indonesia yang berdaulat, mandiri, dan berkepribadian. Revolusi mental dapat disebut juga sebagai gerakan hidup baru (new life) bangsa Indonesia (Budimanta, dkk., 2015b, 2015a).Gerakan ini sejalan dengan gagasanTrisakti Soekarno, yaitu: (1) Indonesia yang berdaulat secara politik, (2) Mandiri secara ekonomi, dan (3) Berkepribadian secara sosial budaya. Bagi Soekarno, secara politik bangsa Indonesia harus berdaulat, dan secara ekonomi harus mandiri (Soekarno, 2015).

Penanaman pendidikan karakter berbasis revolusi mental dapat diimplementasikan melalui Strategi internalisasi pada jalur pendidikan dilakukan melalui empat cara, yaitu: (1) Memperkuat kurikulum pendidikan kewarganegaraan pada semua jenjang, jenis dan jalur pendidikan untuk membangun integrasi, membentuk etos kerja keras dan semangat gotong royong, (2) Menerapka ekstra kurikuler revolusi mental di sekolah dan madrasah, (3) Meningkatkan sarana pendidikan yang merata, dan (4) Meningkatkan kompotensi guru dalam mendukung revolusi mental (Cahyadi, 2016: 21). Oleh karena itu yang menjadi problem adalah bagaimana implementasi pendidikan karakter kebangsaan guru Madrasah Aliyah sebagai bagian program dari gerakan nasioanal revolusi mental di Kabupaten Demak.

Penelitian ini mengunakan Metode Riset Lapangan (field research) dengan teknik analisis deskriptif kualitatif. Data penelitian yang terkumpul dari wawancara, observasi, dan dokumentasi tentang pendidikan karakter sebagai basis revolusi mental yang dilakukan oleh guru Madrasah Aliyah (MA) di Kabupaten Demak kemudian temuan tentang pendidikan karakter sebagai basis revolusi mental kebangsaan guru Madrasah Aliyah di Kabupaten Demak dianalisis dengan menggunakan pendekatan deduktif dan pendekatan induktif.

\section{B. Pembahasan}

\section{Pendidikan Karakter Kebangsaan}

Pendidikan ialah usaha sadar manusia meningkatkan kepribadian di dalam maupun di luar sekolah dan berlangsung seumur hidup (long life) (Janah, 2013; 


\section{Saiful Mujab}

Yusuf, 2012). Oleh karena itu, supaya pendidikan dapat ditempuh oleh semua rakyat yang sesuai dengan kemampuan masyarakat, maka pendidikan adalah tanggung jawab semua pihak, baik keluarga, tenaga pendidik, masyarakat dan pemerintah (Koesoema, 2015: 45). Menurut Amanda Taylor (2017) pendidikan ialah suatu program atau proses pematangan semua potensi yang dipunyai peserta didik, baik potensi jasmani maupun potensi kejiwaan. Sedang menurut Azyumardi Azra (2010), pendidikan adalah sebagai proses pembentukan generasi muda untuk menjalani kehidupan dan memenuhi tujuan hidup secara efektif dan efisien.

Sementara kata karakter secara bahasa (etimologis) berasal dari bahasa Yunani "kasairo" berarti "cetak biru”, "format dasar", "sidik" seperti sidik jari. Dalam hal ini karakter adalah given atau sesuatu yang telah ada dari sananya. Karakter juga dapat disebut "watak", yaitu paduan segala tabiat manusia yang bersifat tetap, sehingga menjadi ciri khusus yang membedakan orang satu dengan yang lain. Karakter atau watak terjadi karena perkembangan dasar yang telah terpengaruh, oleh sebab itu dinamakan pendidikan karakter.

Menurut Doni Koesoema (2015: 46), orang yang berkarakter adalah seperti orang menumbuhkan dan merencanakan masa depannya (future) sendiri, ia tidak bersedia dikuasai oleh kondisi kodrati yang menghalangi pertumbuhannya. Terapi, ia menguasai, mengembangkan demi menjadi manusia yang paripurna. Sedangkan dalam arti etis, karakter harus memiliki nilai-nilai yang baik menunjukkan sifatsifat yang selalu dapat dipercaya, sehingga orang yang berakter itu menujukkan sifat mempunyai pendirian teguh, baik, terpuji, dan dapat dipercaya.Berkarakter berarti memiliki prinsip dalam arti moral dimana perbuatan dan tingkah lakunya dapat dipertanggungjawabkan dan teguh pendirian (Munir, 2010: 16).

Dari beberapa definisi tersebut dapat disimpulkna, bahwa karakter adalah cara pandang dan berperilaku yang menjadi karakteristik setiap individu untuk hidup dan bekerjasama baik dalam lingkungan keluarga, masyarakat, bangsa dan negara. Pribadi yang berkarakter adalah pribadi yang dapat menciptakan keputusan dan siap bertanggungjawab setiap dari keputusan yang individu buat. Karakter merupakan bagian dari nilai-nilai perilaku individu yang memiliki hubungan 


\section{Saiful Mujab}

dengan Tuhan Yang Maha Esa, personal, antar manusia, lingkungan, dan kebangsaannya yang teruwujud dalam pikiran, sikap, perasaan, ucapan, dan perbuatan berdasar pada norma-norma agama, hukum, susila, budaya dan adat istiadat.

Sementara pendidikan karakter menurut Character Education Partnership (CEP), yaitu: pendidikan karakter adalah usaha proaktif yang disengaja oleh sekolah, masyarakat, dan pemerintah sebagai bagian menanamkan hal-hal terpenting bagi peserta didik, seperti nilai-nilai etika,yaitu kepedulian, kejujuran (Siddiq), keadilan, tanggung jawab, dan menghormati diri sendiri dan orang lain. (Walters, Piha, \& Cruz, 2015: 2). Menurut Albertus Doni Koesoema (2015: 194), pendidikan karakter adalah upaya yang dilakukan secara peronal dan sosial dalam mewujudkan lingkungan yang nyaman bagi pertumbuhan bangsa dan demokratis bagi manusia itu sendiri. Pendidikan karakter berhubungan dengan bagaimana seorang memikirkan kebebasan dalam relasinya dengan orang lain sebagai manusia, maupun sebagai mahluk sosial yang ada dalam sebuah struktur yang mempunyai otoritas (Koesoema, 2015: 42).

Pendidikan karakter di dalamnya melibatkan berbagai macam nilai, seperti nilai agama, moral, nilai umum, dan nilai-nilai kewarganagaraan (Munir, 2010: 1946). Persoalan pokok muncul berkaitan dengan internalisasi nilai dalam pendidikan karakter, terutama terkait dengan pemilihan nilai. Tentu saja untuk kasus di Indonesia, pemerintah dan lembaga pendidikan bisa membangun karakter bangsa dari falsafah hidup para pendiri negeri dan budaya yang berkembang di masyarakat.

Menurut Albertus Doni Koesoema (2015: 208-211), nilai-nilai yang bisa ditumbuhkan dalam pendidikan karakter antara lain: (a) nilai keutamaan, (b) nilai keindahan, (c) nilai kerja, (d) nilai cinta tanah air, (e) nilai demokrasi, (f) nilai kesatuan, (g) mengikuti nilai moral, dan (h) nilai-nilai kemanusiaan.Sedangkan manurut Diana Tillman (2004: xx-xxi), unit-unit nilai karakter meliputi sembilabn hal, yaitu: (a) kedamaian, (b) penghargaan, (c) cinta, (d) toleransi, (e) kebahagiaan, (f) tanggung jawab, (g) kerjasama, (h) kerendahan hati, (i) kejujuran, (j) kesederhanaan, (k) kebebasan, dan (l) persatuan. 


\section{Saiful Mujab}

Pendidikan budaya dan karakter kebangsaan dilakukan dengan pendidikan nilai-nilai atau kebajikan yang menjadi nilai dasar budaya dan karakter bangsa. Kebajikan yang menjadi atribut suatu karakter pada dasarnya adalah nilai. Oleh karena itu pendidikan budaya dan karakter kebangsaan pada dasarnya adalah pengembangan nilai-nilai yang bersumber dari pandangan hidup atau ideologi bangsa Indonesia, agama, budaya, dan nilai-nilai yang terumuskan dalam tujuan pendidikan nasional.

Karakter sebuah bangsa merupakan indikator penting yang berkorelasi pada pertumbuhan sosial-ekonomi bangsa tersebut. Kualitas karakter yang baik dari masyarakatnya akan mengembangkan kualitas bangsa tersebut. Beberapa ahli berkeyakinan bahwa pengembangan karakter yang paling baik adalah jika dilaksanakan sejak usia dini. Menurut Sunaryo Kartadinata (2012), karakter kebangsaan bukan serangan karakter individu, karena karakter bangsa harus diwujudkan dalam rasa kebangsaan yang tinggi dalam konteks budaya yang beragam. Karakter kebangsaan memiliki pemersatu kultural, yang mesti diwujudkan dalam kesadaran budaya (cultural awreness) dan kecerdasan budaya (cultural intelligence) setiap warga negara. Pada Kebijakan Nasional Pembangunan Karakter Bangsa, disebutkan bahwa karakter kebangsaan adalah kualitas perilaku kolektif kebangsaan yang baik yang tecermin dalam kesadaran, pemahaman, rasa, karsa, dan perilaku berbangsa dan bernegara sebagai produk olah pikir, olah hati, olah rasa dan karsa, serta olah raga seseorang atau sekelompok orang. Karakter bangsa Indonesia akan menentukan perilaku kolektif kebangsaan Indonesia yang khas-baik yang tecermin dalam kesadaran, pemahaman, rasa, karsa, dan perilaku berbangsa dan bernegara Indonesia yang berdasarkan pada nilai-nilai Pancasila, norma UUD 1945, keberagaman dengan berpedoman pada Bhinneka Tunggal Ika, dan komitmen terhadap NKRI (Dharmawan, 2014).

\section{Revolusi Mental}

Revolusi biasa didefinisikan sebagai perubahan yang belangsung dengan cepat. Artinya, perubahan tersebut terjadi dalam waktu yang pendek. Akan tetapi, 


\section{Saiful Mujab}

sebagaimana diketahui, cepat atau pendek ini relatif sifatnya. Revolusi industri di Inggris misalnya, bukanlah sebuah revolusi yang berlangsung dengan cepat. Diperlukan waktu bertahun-tahun untuk bisa muncul berbagai penemuan dalam ilmu pengetahuan, yang kemudian bersama-sama menghasilkan berbagai perangkat teknologi yang begitu mengubah kehidupan manusia. Istilah revolusi di sini lebih ditujukan pada dampak yang dihasilkan dari perubahan yang terjadi, sebagaimana halnya juga istilah revolusi dalam "Revolusi Neolitik".

Jika demikian Revolusi Mental dapat didefinisikan sebagai perubahanperubahan mendasar (fundamental) yang terjadi pada kerangka pemikiran individu, yang berdampak luas dan penting terhadap lingkungan tempat individu tersebut berada. Definisi ini tidak serta-merta dapat dipahami, karena di dalamnya terdapat sejumlah konsep atau istilah yang memang perlu dijelaskan lebih lanjut. Untuk itu, definisi ini dapat dibagi menjadi beberapa frase yang menunjukkan suatu pengertian tertentu.

Penggunaan term revolusi mental sebenarnya ada yang melihatnya sebagai sebuah konsep yang lebih mengarah kepada sekularistik, dimana unsur-unsurnya bekerja pada wilayah-wilayah empirik sebagai sebuah konsep dasar keilmuan modern sekarang (Suasta, 2014: 48). Sebagai sebuah konsep, revolusi mental lebih berfokus pada perbaikan paradigm dan mindset pelakunya sebagai penopang penyelenggaraan sebuah tatanan birokrasi Pemerintahan.20 Dengan kata lain, birokrasi harus mampu memenuhi kewajiban dan tampil sebagai pelayan publik dengan semangat efektifitas, efesiensi, transparan dan akuntabel.

Manusia sebagai pusat sekaligus pelaku revolusi mental harus di-drive untuk memiliki cara pandang, cara merasa, cara meyakini, dan cara bersikap dan berprilaku yang didasarkan pada konsep norma, nilai, dan juga konsep agama. Sebagaimana yang sering kita dengar, kalau tidak bisa diukur oleh parameter empirik maka tidak bisa disebut ilmiah. Terlepas dari sikap yang memandang term tersebut terlalu sekular, revolusi mental tetap dipandang sebagai sebuah konsep yang mampu menjawab kebutuhan bangsa ini akan sebuah sikap yang positif dalam segala hal yang berhubungan dengan cara berfikir, cara memandang masalah, cara 


\section{Saiful Mujab}

merasa, meyakini (mempercayai), serta cara berprilaku dan bertindak (Syukron, 2016).

Dalam UU RI Nomor 20 Tahun 2003 tentang Sisdiknas Bab II Pasal (3) disebutkan bahwa pendidikan nasional berfungsi mengembangkan kemampuan dan membentuk watak serta peradaban bangsa yang bermartabat dalam rangka mencerdaskan kehidupan bangsa, bertujuan untuk berkembangnya potensi peserta didik agar manusia yang beriman dan bertakwa kepada Tuhan Yang Maha Esa, berakhlak mulia, sehat, berilmu, cakap, kreatif, mandiri, dan menjadi warga Negara yang demokratis serta bertanggung jawab. Dari tujuan itu bahwa dikatakan manusia sebagai manusia berjati diri bangsa Indonesia jika seseorang memiliki mental seperti itu. Maka sebagai implikasinya agar tercapai kriteria-kriteria tersebut mau tidak mau harus melalui pendidikan dan pembudayaan di masyarakat. Mental berkaitan dengan batin yang mewujud dalam cara berpikir, cara merasa, dan cara bersikap atau meyakiniyang melahirkan tindakan. Menurut Poerwadarminta (2006: 762) bahwa mentalitas berarti keadaan batin; cara berpikir dan ber-perasaan. Sedangkan revolusi mental pada hakikatnya mengisi mental manusia dengan nilainilai luhur (nilai agama, nilai tradisi budaya dan nilai falsafah bangsa) secara besar-besaran sehingga terbentuk karakter baik (good character). Acuan revolusi mental good character yang berbasis Islam dan filsafat pendidikan ialah QS. Rum (30): 30 dan karakteristik Islam. Menurut Yusuf al-Qardhawi (1983: vii) karakteristik Islam ialah rabbaniyah (ketuhanan), insaniyah (kemanusiaan), syumul (universal) untuk semua zaman, tempat dan manusia, al-wasthiyyah (pola keseimbangan atau keadil-an), al-waqi'iyyah (berpijak pada kenyataan objektif manusia), al-wudluh (kejelasan), dan integrasi antara tsabat (konsisten) dan murunah (luwes). Dari ayat ini, karakteristik Islam dan filsafat pendidikan melahirkan empat aliran filsafat pendidikan revolusi mental untuk membangun mental good character yaitu (1) fatalis-pasif, (2) netral-pasif, (3) positif-aktif dan (4) dualisaktif (Yasin, 1997: 41-75). Berbeda dengan apa yang dikemukakan oleh Morris L. Bigge (1982: 16) ada empat sifat dasar manusia dan hubungannya dengan 


\section{Saiful Mujab}

alam sekitar yaitu bad-active (jelek-aktif), good-active (baik-aktif), neutral-passive (netral-pasif) dan neutralin-teractive (netral-interaktif).

\section{Implementasi Pendidikan Karakter Sebagai Gerakan Revolusi Mental Guru MA di Demak}

Implementasi pendidikan karakter sebagai basis revolusi mental guru Madrasah Aliyah di Demak secara normatif merujuk pada al-Qur'an dan hadis, mengacu kepada dua kata dalam Alquran yakni materi diwakili dengan kata basyar dan jism dan immateri diwakili dengan kata insan. Kata basyarah mengacu pada aspek lahiriah atau prilaku yang dapat tumbuh secara alami sesuai dengan makanan dan minuman yang dikonsumsinya (QS. al-Baqarah, [2]:247) dan (QS. alMunafiqun, [63]: 4). Kedua ayat ini menunjukkan bahwa kekuatan fisik dapat membantu seseorang dalam menjalankan tugas mora-lnya dan menjerumuskan seseorang ke da-lam maksiat (tuna karakter). Keperkasaan tubuh merupakan modal untuk sehat mental. Sedangkan kata insanberasal dari tiga kata yaitu anasa, nasiya, dan anisa. Kata anasa berarti (1) melihat, mengetahui, dan minta izin, kata (2) nasia berarti lupa, dan kata (3) anisa berarti jinak. Dari kata insan memberi petunjuk adanya kaitan sub-stansial antara manusia dengan kemampuan penalaran, manusia lupa terhadap sesuatu hal, disebabkan ia kehilangan kesadaran terhadap sesuatu. Oleh karena itu, dalam Islam dibenar- Islam dibenarkan, orang yang lupa tidak dibebani hukum, orang yang lupa tidak dibebani hukum atau tidak diminta pertanggung jawaban. Disamping itu manusia adalah makhluk yang jinak, yang berbudaya, dan dapat mendidik dan dididik serta dapat beradaptasi dengan lingkungan baik lingkungan alam maupun lingkungan sosial. Dengan potensi kemampuan ber-adaptasi, manusia perlu direvolusi mental-nya dengan pemberian ilmu, yang dengan ilmu itu mempercepat manusia mampu beradaptasi dengan lingkungan alam dan sosial budaya dan mempersiapkan diri dengan berbagai ilmu untuk mampu beradaptasi di masa yang akan datang yang tantangannya lebih kompleks dan global. Jati diri manusia dapat dididik (educandus/ dipengaruhi) dan mendidik (educandum/ mempengaruhi) dalam kerang-ka revolusi mental. Sebagai konsekwensi predikat educandum dan educandus itu, maka Allah memberikan 


\section{Saiful Mujab}

perangkat fitrah (sistem dan kecenderungan asli) berupa potensi internal yakni aql (akal), qalb (hati-spiritual), dan nafs (sisi dalam manusia yang berpotensi baik dan buruk) dan potensi eksternal yaitu kelenturan fisik. Berikut penjelasan yang berkaitan dengan aspek-aspek mental yakni: Pertama, Alat bagi mental ialah aspekakal termasuk kata lubb yang searti dengan akal (al-Bantani, 1995).

Sejalan dengan pendapat Syekh Nawawi tersebut dan dihubungkan dengan Alquran, maka akal adalah alat bagi mental yang berfungsi untuk:(1) memahami dan menggambarkan sesuatu agar seseorang mencapai hakikat yang menuntunnya ber-iman kepada- Nya (QS. Al-Baqarah, [2]:73), (2) penuntun seseorang memahami hakikat kebenaran yang mengantarkannya kepada keimanan (QS. alBaqarah [2]:164-165, al-An'am [6]:50, al-Rum [30]:19-21, alBaqarah [2]:197, alGasyiyah [88]:17, dan Shad [38]:29,(3) daya dorong bermoral (QS. Al-An'am [6]:151, (4) mengambil hikmah dari sesuatu peristiwa (QS. AlBaqarah (2):186), dan (5) alat dzikrullah (berzikir/mengingat kepada Allah) dan alat memikirkan ciptaan Allah (Maragustam, 2015). Sedangakn secara yuridis implementasi pendidikan karakter sebagai gerakan revolusi mental guru Madrasah Aliyah di Demak merujuk pada Pancasila, UUD 1945, UU No. 20 Tahun 2003, Perpres No. 87 Tahun 2017, PergubProvinsi Jawa Tengah No. 31 Tahun 2016, Perbup Kabupaten Demak No. 24 Tahun 2017, dan Perbup No. 75 Tahun 2017.

Implementasi pendidikan karakter kebangsaan guru Madrasah Aliyah di Demak selaras dengan tujuan pendirian NKRI seperti ditegaskan dalam Pembukaan UUD 1945 yaitu melindungi segenap bangsa Indonesia dan seluruh tumpah darah Indonesia,memajukan kesejahteraan umum,Mencerdaskan kehidupan bangsa, melaksanakan ketertiban dunia yang berdasarkan kemerdekaan, perdamaian abadi dan keadilan sosial. Dapat disimpulkan tujuan Negara Republik Indonesia adalah tujuan perlindungan,kesejahteraan,pencerdasan,dan pedamaian. Tujuan pendirian NKRI juga termaktub dalam Tap MPR Nomor X/MPR/1998 yaitu Pancasila sebagai dasar negara Republik Indonesia telah bersifat final. Artinya menjadi kesepakatan nasional yang diterima secara luas oleh rakyat Indonesia. 


\section{Saiful Mujab}

Tujuan implementasi pendidikan karakter berbasis revolusi mental yang dilakukan oleh guru Madrasah Aliyah di Demak, adalah: (1) membangun dan membekali peserta didik sebagai generasi emas Indonesia tahun 2045 dengan jiwa Pancasila, (2) mengembangkan platform pendidikan nasional yang meletakkan pendidikan karakter sebagai jiwa utama dalam menyelenggarakan pendidikan, (3) memvitalisasi dan memperkuat potensi dan kompetensi pendidik, tenaga kependidikan, peserta didik, masyarakat, dan lingkungan keluarga(4) membangkitkan kesadaran dan membangun sikap optimis sebagai bangsa Indonesia, (5) memantapkan jati diri waga Jawa Tengah yang bangga terhadap nilai-nilai luhur bangsa dan kearifan local, (6) mewujudkan masyarakat Jawa Tengah yang berdaulat secara politik, mandiri secara ekonomi, dan berkepribadian dalam kebudayaan.

Sedangkan Penguatan pendidikan karakter sebagai basis revolusi mental yang dilakukan oleh guru Madrasah Aliyah di Demak sejalan dengan program Nawacita Presiden Joko Widodo (2014-2019) dan Trisakti Presiden Soekarno. Nawacita adalah istilah umum yang diambil dari bahasa sansekerta nawa artinya sembilan dan cita artinya harapan, keinginan, impian. Nawacita yaitu sembilan harapan, keinginan, impian dari Bapak Joko Widodo untuk kesejahteraan rakyat Indonesia. Bapak Joko Widodo menggunakan istilah Nawacita ini untuk keperluan politik saat beliau mencalonkan diri sebagai Presiden dan Bapak Jusuf Kalla sebagai calon Wakil Presiden pada Pemilihan Umum tahun 2014. Nawacita digunakan sebagai visi-misi beliau apabila terpilih menjadi Presiden dan Wakil Presiden pada Pemilu tahun 2014-2019. Visi-misi Bapak Joko Widodo dan Bapak Jusuf Kalla berisi sembilan pokok agenda prioritas untuk melanjutkan semangat perjuangan dari Soekarno yang dikenal sebagai Trisakti yaitu berdaulat secara politik, mandiri dalam ekonomi, dan berkepribadian dalam kebudayaan.

Progam Nawacita Bapak Joko Widodo dan Bapak Jusuf Kalla meliputi melindungi segenap bangsa dan memberikan rasa aman pada semua warga negara, Pemerintah selalui hadir dalam membangun pengelolaan Pemerintahan yang bersih, efektif, demokratis, dan terpercaya, membangun Indonesia dari wilayah terluar 


\section{Saiful Mujab}

dengan memperkokoh daerah-daerah dan Desa dalam kerangka Negara Kesatuan. Menolak Negara lemah dengan melaksanakan reformasi birokrasi dan penegakan hukum yang bebas korupsi, bermartabat dan terpercaya, mengembangkan kualitas hidup masyarakat Indonesia diwujudkan dengan meningkatkan kualitas pendidikan, kesehatan dan kerja masyarakat Indonesia, meningkatkan peran serta rakyat dan daya saing di pasar internasional, menciptakan kemandirian ekonomi dengan menggerakan sektor sektor strategis ekonomi domestik, melaksanakan revolusi karakter bangsa diimplementasikan melalui kebijakan pengelolaan kembali kurikulum pendidikan nasional dengan menutamakan aspek pendidikan kewarganegaraan (civic education), dan memperteguh Ke-Bhineka-an dan memperkuat restorasi sosial Indonesia (Halimah, 2017).

Pada hakikatnya, pembentukan watak ini dilandasi oleh potensi-potensi inteligensi yang ada di dalam diri manusia. Adalah umum kita dengar bahwa intelegensi yang harus dibangkitkan dan diasah di dalam diri seorang individu mencakupi ranah kecerdasan intelektual, kecerdasan spiritual, dan kecerdasan emosional. Kecerdasan spiritual dan kecerdasan emosional merupakan sarana untuk menumbuhsuburkan akar karakter seseorang. Kecerdasan intelektual akan dengan sendirinya terisolasi bila tidak didukung oleh kedua kecerdasan lainnya tersebut. Brenneman (2009: 4-6) memperluas kecerdasan ini menjadi 6, yaitu kecerdasan spiritual, kecerdasan fisik, kecerdasan mental, kecerdasan emosi, kecerdasan sosial, dan kecerdasan karir. Secara lebih terperinci, kecerdasan-kecerdasan ini dapat diasosiasikan dengan pilar-pilar pendidikan karakter. Ada banyak sumber yang mendeskripsikan tentang pilar-pilar pendidikan karakter, namun dalam tulisan ini, nilai dasar pendidikan karakter kebangsaan guru Madrasah Aliyah di Demak merujuk pada enam pilar yang disebutkan oleh Major (2008: 19).

a. Trustworthiness (Keterpercayaan). Pilar pertama ini mengandung unsurunsur berikut: 1) kejujuran, yang merefleksikan keengganan untuk berbohong, menipu, atau mencuri; 2) reliabilitas, yang mencakupi pemenuhan komitmen, kepatuhan akan aturan dan kode etik yang mengikat; 3) keberanian bertindak atas 


\section{Saiful Mujab}

dasar kebenaran; 4) pembangunan reputasi yang baik; dan 5) kesetiaan, baik pada keluarga, teman, dan negara.

b. Rasa Hormat. Komponen pembangun karakter ini adalah 1) menghargai dan memperlakukan orang lain dengan hormat; 2) bertenggang rasa dan menerima berbagai perbedaan; 3) berperilaku baik dan menghindari kata-kata kasar; 4) mempertimbangkan perasaan orang lain; 5) tidak mengancam, memukul atau mencederai orang lain; dan 6) menahan amarah, tidak menghina orang lain, dan tidak memaksakan ketidaksetujuan pada orang lain.

c. Bertanggungjawab. Bertanggungjawab dipahami dalam beberapa perspektif seperti melaksanakan kewajiban, membuat perencanaan, ketangguhan, berusaha melakukan yang terbaik, pengendalian diri, disiplin, berpikir sebelum bertindak, bertanggungjawab atas ucapan, perbuatan, dan sikap, dan menjadi teladan bagi orang lain.

d. Fairness (adil). Pengertian fairness adalah kesediaan untuk bertindak adil bagi diri sendiri dan orang lain. Tindakan adil ini diindikasikan oleh kesediaan untuk mengikuti aturan main, memberikan kesempatan pada diri sendiri dan orang lain, berpikiran terbuka (mau mendengar orang lain), tidak memanfaatkan orang lain, tidak menyalahkan orang lain dengan semena-mena, dan memperlakukan orang lain secara adil.

e. Keperdulian. Secara nyata keperdulian ditandai oleh keramahan/kebaikan hati, simpati dan empati, rasa terima kasih, kemauan memaafkan orang lain, dan membantu orang yang tengah membutuhkan.

f. Citizenship (Rasa Persatuan). Nilai-nilai rasa persatuan ini dimanifestasikan dalam bentuk kontribusi nyata untuk membuat komunitas tempat ia berada menjadi lebih baik, bekerjasama dengan orang lain, terlibat dalam kegiatan-kegiatan kemasyarakatan, terus mengikuti perkembangan informasi, menjadi anggota masyarakat yang baik, mematuhi hukum dan perundangundangan, menghargai para pemimpin, perduli pada lingkungan, dan kesukarelaan.

Dalam konteks Indonesia, pilar-pilar karakter ini telah terkandung di dalam Undang-Undang Dasar 1945 dan Pancasila. Nilai-nilai moral dan sosial secara 


\section{Saiful Mujab}

gamblang dinyatakan di sana yang berujung pada pewujudan perdamaian dunia. Secara tradisional, dalam sistem pendidikan kita nilai-nilai yang terdapat dalam pilar-pilar tersebut sering diasosiasikan dengan konsep-konsep agama, budaya, dan kebangsaan, sehingga selalu dibebankan pada pelajaran-pelajaran tertentu seperti Agama dan Kewarganegaraan. Padahal, dalam praktiknya, pembelajaran Agama dan Kewarganegaraan sendiri belum menganut pengintegrasian pendidikan karakter secara nyata di dalamnya.

Agustian dalam Madji (2007) menangkap bahwa terminologi-terminologi semacam conciousness, code ethic, inner voice, core value, dan sebagainya pada dasarnya merupakan penerapan suara hati atau nilai-nilai kebajikan dalam kehidupan. Ia melanjutkan, jika nilai-nilai mulia seperti integritas, komitmen, disiplin, kerjasama, semangat, bijaksana, visioner, dan lain-lainnya, diaplikasikan dalam bisnis, organisasi, sekolah, maupun rumah tangga, maka niscaya sukses yang diharapkan akan dapat digapai. Nilai-nilai luhur ini bila menjelma dalam konteks pluralistik Indonesia akan muncul semangat satu untuk semua dan semua untuk satu. Kompetensi yang terbangun adalah kompetisi sehat, yaitu untuk mencapai tujuan bersama (Hartoyo, 2010).

Sedangkan Ruang lingkup pendidikan karakter sebagai basis revolusi mental yang dilakukan oleh guru Madrasah Aliyah di Demak, adalah: (1) Penguatan kelembagaan politik dan reformasi birokrasi pemerintahan, (2) Peningkatan kemandirian ekonomi dan daya saing daerah, (3) Pembangunan pendidikan berkualitas dan kebudayaan yang memacu daya cipta dan inovasi, (4) Pemanfaatan secara efektif modal sosial, modal budaya dan modal intelektual, (5) Pengembangan kepribadian dan jati diri bangsa, dan (6) Pelaksanaan melalui jalur pendidikan formal, nonformal, dan informal. Dengan berprinsip pada pelaksanaan pendidikan karakter kebangsaan guru Madrasah Aliyah di Kabupaten Demak, yaitu: (1) Berorientasi pada berkembangnya potensi peserta didik, (2) Keteladanan dalam penerapan pendidikan karakter, (3) Berlangsung melalui pembiasaan dan sepanjang waktu. Dengan prinsip-prinsip, yaitu: (a) Prinsip gerakan sosial, (b) Prinsip dukungan politik, (c) Prinsip lintas sektor, (d) Prinsip kolaborasi, (e) Prinsip 


\section{Saiful Mujab}

perubahan, (f) Prinsip popular, (g) Prinsip pengaturan kehidupan sosial, (h) Prinsip keterukuran, dan (i) Prinsip keberlanjutan.

\section{Simpulan}

Implementasi pendidikan karakter sebagai basis revolusi mental yang dilakukan oleh guru Madrasah Aliyah di Demak, yaitu: Secara normatif merujuk pada al-Qur'an dan hadis, secara hukum merujuk pada Pancasila, UUD 1945, UU No. 20 Tahun 2003, Perpres No. 87 Tahun 2017,PergubProvinsi Jawa Tengah No. 31 Tahun 2016, Perbup Kabupaten Demak No. 24 Tahun 2017, dan Perbup No. 75 Tahun 2017. Kedua, tujuan implemetasi pendidikan karakter sebagai basis revolusi mental yang dilakukan oleh guru Madrasah Aliyah di Demak selaras dengan tujuan pendirian NKRI seperti ditegaskan dalam Pembukaan UUD 1945 dan Tap MPR Nomor X/MPR/1998 yaitu: (1) membangun dan membekali peserta didik sebagai generasi emas Indonesia tahun 2045 dengan jiwa Pancasila, (2) mengembangkan platform pendidikan nasional yang meletakkan pendidikan karakter sebagai jiwa utama dalam menyelenggarakan pendidikan, (3) memvitalisasi dan memperkuat potensi dan kompetensi pendidik, tenaga kependidikan, peserta didik, masyarakat, dan lingkungan keluarga(4) membangkitkan kesadaran dan membangun sikap optimis sebagai bangsa Indonesia, (5) memantapkan jati diri waga Jawa Tengah yang bangga terhadap nilai-nilai luhur bangsa dan kearifan local, (6) mewujudkan masyarakat Jawa Tengah yang berdaulat secara politik, mandiri secara ekonomi, dan berkepribadian dalam kebudayaan. Ketiga, penguatan pendidikan karakter sebagai basis revolusi mental yang dilakukan oleh guru Madrasah Aliyah di Demak sejalan dengan program Nawacita Presiden Joko Widodo (2014-2019) dan Trisakti Presiden Soekarno. Keempat, nilai dasar pendidikan karakter sebagai basis revolusi mental yang dilakukan oleh guru Madrasah Aliyah di Demak berpedoman pada enam pilar utama, yaitu: Pilar trustworthiness (kepercayaan), pilar recpect (respek), pilar responsibility (tanggungjawab), pilar fairness (keadilan), pilarcaring (peduli), pilarcitizenship (kewarganegaraan). Kelima, ruang lingkup pendidikan karakter 
sebagai basis revolusi mental yang dilakukan oleh guru Madrasah Aliyah di Demak, yaitu: (1) Penguatan kelembagaan politik dan reformasi birokrasi pemerintahan, (2) Peningkatan kemandirian ekonomi dan daya saing daerah, (3) Pembangunan pendidikan berkualitas dan kebudayaan yang memacu daya cipta dan inovasi, (4) Pemanfaatan secara efektif modal sosial, modal budaya dan modal intelektual, (5) Pengembangan kepribadian dan jati diri bangsa, dan (6) Pelaksanaan melalui jalur pendidikan formal, nonformal, dan informal. Keenam, prinsip pelaksanaan pendidikan karakter sebagai basis revolusi mental yang dilakukan oleh guru Madrasah Aliyah di Demak, yaitu: (1) Berorientasi pada berkembangnya potensi peserta didik, (2) Keteladanan dalam penerapan pendidikan karakter, (3) Berlangsung melalui pembiasaan dan sepanjang waktu. Dengan prinsip-prinsip, yaitu: (a) Prinsip gerakan sosial, (b) Prinsip dukungan politik, (c) Prinsip lintas sektor, (d) Prinsip kolaborasi, (e) Prinsip perubahan, (f) Prinsip popular, (g) Prinsip pengaturan kehidupan sosial, (h) Prinsip keterukuran, dan (i) Prinsip keberlanjutan.

\section{Daftar Pustaka}

al-Bantani, N. (1995). Maraqi al-'Ubudiyah, Syarh'ala Matn Bidayah al-Hidayah. Semarang: Toha Putra.

Aman, A. (2016, January). Peran Pendidikan dalam Revolusi Mental. Presented at the Prosiding Seminar Ilmiah STABN, Tangerang.

Asrori, M. Abdur Rozak. (2016). Peran Pendidikan Karakter Melalui Revolusi Mental untuk Membangun Generasi Bangsa. Jurnal Rontal Keilmuan PPKn, 2, No. 2.

Asrori, Mohamad Abdul Roziq. (2017). PERAN PENDIDIKAN KARAKTER MELALUI REVOLUSI MENTAL UNTUK MEMBANGUN GENERASI BANGSA. Jurnal Rontal Keilmuan Pancasila Dan Kewarganegaraan, 2(2). https://doi.org/10.29100/ppkn.v2i2.343

Azra, A. (2010, July 3). Pendidikan Karakter: Peran Gerakan Perempuan. Presented at the Muktamar 'Aisyiah ke 46, Yogyakarta.

Bigge, M. L. (1982). Learning Theories for Teachers. USA: Harper and Row Publishers.

Brenneman, K. D. (2009). Tes IQ: Untuk Mengembangkan Kecakapan Menghadapi Hidup. Las Vegas: Putman \& Putman. 
Budimanta, dkk., A. (2015a). Panduan Pencanangan dan Sosialisasi Gerakan Nasional Revolusi Mental. Jakarta: Kemenko Bidang Pembangunan Manusia dan Kebudayaan.

Budimanta, dkk., A. (2015b). Panduan Umum Revolusi Mental. Jakarta: Kemenko Bidang Pembangunan Manusia dan Kebudayaan.

Cahyadi, F. (2016). Revolusi Mental Demi Menuju Indonesia Emas. Bandung: Jaya Fiolfa.

David, W. L. (2005). Corruption As A Transitional Phenomenon: Understanding Endemic Corruption in Postcomunist States," In Corruption: Anthropological Perspectives (H. Dieter \& S. Cris, Eds.). London: An Arbor, MI-Pluto Press.

Dharmawan, N. S. (2014). IMPLEMENTASI PENDIDIKAN KARAKTER BANGSA PADA MAHASISWA DI PERGURUAN TINGGI. Pembinaan Pendidikan Karakter bagi 1 Mahasiswa PTS di Lingkungan Kopertis Wilayah VII.

Edward, A., \& Markus, M. (2010). Problems of Democratisation in Indonesia: An Overview, "In Problems of Democratisation in Indonesia: Elections, Institutions and Society. Singapura: Institute of Southeast Asian Studies.

Fatmawati, N. (2020). "Gaya Hidup Mahasiswa Akibat Adanya Online Shop". Jurnal Pendidikan Ilmu Sosial, 29 (1): 29-38.

Halimah, F. (2017). Studi Deskriptif Penerapan Program Nawacita Presiden Joko Widodo Tentang Membangun Indonesia Dari Pinggiran Terhadap Kesejahteraan Warga Di Desa Kanoman Kecamatan Panjatan Kabupaten Kulon Progo (Universitas PGRI Yogyakarta). Universitas PGRI Yogyakarta, Yogyakarta. Retrieved from http://repository.upy.ac.id/1684/

Hamudy, Moh. I. A. (2010). Negosiasi dalam Reformasi Pemerintahan Daerah. Jurnal Ilmu Administrasi Dan Organisasi, 17(1), 52-60.

Hartoyo, I. (2010). PENGINTEGRASIAN PILAR-PILAR PENDIDIKAN KARAKTER DALAM PROSES PEMBELAJARAN DI PERGURUAN TINGGI. BAHAS, O(79 TH 37). https://doi.org/10.24114/bhs.v0i79 TH 37.2630

Ida, L. (2014). Election and Political Evil Ambition in Indonesia's Reformasi Era. International Journal of Politics Ang Goog Governance, 4(54).

Janah, F. (2013). Pendidikan Seumur Hidup dan Implikasinya. Dinamika Ilmu, 13, No. $1,1-15$.

Kardi, K. (2014). Demokratisasi Relasi Sipil-Militer pada Era Reformasi di Indonesia. Jurnal MASYARAKAT: Jurnal Sosiologi, 19, No. 2, 231-256.

Kartadinata, S. (2012, Nopember). Memantapkan Karakter Bangsa Menuju Generasi 2045: Sistem Pendidikan Yang Memungkinkan Dihasilkannya Pendidik dan Yenaga Kependidikan Yang Kompeten untuk Mempersiapkan Generasi 2045, (, Yogyakarta, ). Konvensi Nasional Pendidikan Indonesia 7. 
Koentjaraningrat. (2015). Kebudayaan Mentalitas dan Pembangunan. Jakarta: Gramedia Pustaka Utama.

Koesoema, A. D. (2015). Pendidikan Karakter, Strategi Mendidik Anak di Zaman Global. Jakarta: Grasindo.

Komara, E. (2015). Sistem Politik Indonesia Pasca Reformasi. Jurnal SISIO DIDAKTIKA: Social Sciences Education Jurnal, 2 No. 2.

Madji, U. Y. E. (2007). Quranic Quotient: Menggali dan Melejitkan Potensi Diri Melalui Al-Qur'an. Tangerang: QultumMedia.

Major, M. R. (2008). The Teacher's Survival Guide: Real Classroom Dilemmas and Practical Solutions. Maryland: Rowman \& Littlefield Education.

Maragustam. (2015). Paradigma Revolusi Mental Dalam Pembentukan Karakter Bangsa Berbasis Sinergitas Islam Dan Filsafat Pendidikan. Jurnal Pendidikan Agama Islam, XII(2).

Munir, A. (2010). Pendidikan Karakter: Membangun Karakter Anak Sejak dari Rumah. Yogyakarta: Pedagogia.

Noor, A. F. (2016). Gerakan Revolusi Mental untuk Meningkatkan Pendidikan Kepribadian Bangsa Warga Negara. Jurnal Pedagogik Jurnal Pendidikan, 11, No. 2, 7-13.

Persada, N. M., \& Pramono, S. E. (2017). Pelibatan Orang Tua Pada Pendidikan Anak Di SD Sains Islam. Al Farabi Sumber Cirebon, 6(405), 100-108.

Poerwadarminta. (2006). Kamus Besar Bahasa Indonesia. Jakarta: Balai Pustaka.

Purnaweni, H. (2004). Demokrasi Indonesia: Dari Masa ke Mas. Jurnal Administrasi Publik, 3(2), 118-130.

Qardhawi, Y. (1983). Al-Khasais Al-Ammah Li Al-Islam: . Beirut: Muassasah alRisalah.

Sholekhah, F. (2019). Pendidikan Karakter melalui Revolusi Mental di Era Disruptif. MODELING: Jurnal Program Studi PGMI, 6(1), 64-88. https://doi.org/10.36835/modeling.v6i1.343

Simorangkir, J. (2015). Islam Pasca Orde Baru. Jurnal Istimbath, 17 No. 16.

Soekarno. (2015). Dibawah Bendera Revolusi. Yogyakarta: Media Pressindo dan Yayasan Bung Karno.

Suasta, P. (2014). Menegakkan Demokrasi, Mengawal Perubahan, Jakarta: Jakarta: Lestari. Kiranamata.

Syukron, B. (2016). PARADIGMA IMPLEMENTASI KONSEP REVOLUSI MENTAL (Studi Analisis Dalama Perspektif Lembaga Pendidikan Islam). Elementary, 2 No. 3. 
Taylor, A. (2017). Character Education: A Bibliography of Recent Research, Reports and Resources. In National Foundation for Educational Research (NFER) Public.

Tilman, D. (2004). Pendidikan Nilai untuk Anak Usia 8-14 Tahun (A. Respati, Trans.). Jakarta: Grasindo.

Walters, S., Piha, S., \& Cruz, R. (2015). Character Education: A Literature Review. USA: Temescal Associates.

Widjiastuti, A. (2016). The Form of Youth Manners Through Mental Revolution: Case Studi in Indonesia. Journal of Law, Policy and Globalization, 46 No. 2.

Yasin, M. (1997). Insan Yang Suci, Konsep Fitrah Dalam Islam (M. Abadi, Trans.). Bandung: Mizan.

Yusuf, A. (2012). Long Life Education-Belajar Tanpa Batas. Jurnal PEDAGOGIA, 1, No. 2, 111-129. 